\title{
RESPON PENAWARAN KACANG TANAH DI INDONESIA
}

\author{
Yonette Maya Tupamahu \\ Staf Pengajar Faperta UMMU-Ternate, e-mail: ymtup@yahoo.co.id
}

\begin{abstract}
ABSTRAK
Penelitian ini bertujuan mengkaji faktor-faktor apa saja yang mempengaruhi respon penawaran dan elastisitas penawaran kacang tanah di Indonesia. Bentuk respon penawaran adalah Model Nerlove dan teknik estimasinya Ordinary Least Square (OLS) menggunakan Eviews 7. Penelitian menggunakan data time series selama 26 tahun yaitu 1990-2015. Hasil penelitian menunjukkan faktor-faktor yang mempengaruhi respon penawaran kacang tanah di Indonesia adalah : harga kacang tanah pada tahun sebelumnya, penawaran kacang tanah pada tahun sebelumnya, harga padi pada tahun sebelumnya, harga kedelai pada tahun sebelumnya, dan produksi kacang tanah pada tahun $t$. Elastisitas penawaran harga sendiri dalam jangka pendek dan panjang bersifat elastis. Sedangkan elastisitas harga silang terhadap harga padi pada tahun sebelumnya dan terhadap harga kedelai tahun sebelumnya bersifat inelastis.
\end{abstract}

Kata kunci: respon penawaran, elastisitas penawaran, kacang tanah

\section{PENDAHULUAN}

\subsection{Latar Belakang}

Sektor pertanian merupakan sektor yang penting dalam perekonomian Indonesia, hal ini terlihat dalam Rencana Pembangunan Jangka Menengah Nasional (RPJMN) tahap ke-3 (20152019) difokuskan untuk memantapkan pembangunan secara menyeluruh dengan menekankan pembangunan kompetitif perekonomian yang berbasis sumberdaya alam yang tersedia, sumberdaya manusia yang berkualitas dan kemampuan penguasaan ilmu pengetahuan dan teknologi. Pembangunan sektor pertanian dalam lima tahun ke depan (2015-2019) akan mengacu pada Paradigma Pertanian untuk Pembangunan (Agriculture for Development) yang memposisikan sektor pertanian sebagai penggerak transformasi pembangunan yang berimbang dan menyeluruh mencakup transformasi demografi, ekonomi, intersektoral, spasial, institusional, dan tatakelola pembangunan (Kementerian Pertanian, 2015a).

Salah satu program sasaran yang ingin dicapai adalah peningkatan produksi, produktivitas dan mutu hasil produksi tanaman pangan salah satunya pengelolaan tanaman aneka kacang. Diantara aneka tanaman kacang, maka kacang tanah merupakan bahan pangan yang mengandung kalori tertinggi. Kacang tanah pun dapat diolah menjadi berbagai produk pangan oleh industri rumah tangga hingga industri besar, sehingga mendorong permintaan kacang tanah.

Secara teori pun permintaan suatu barang termasuk kacang tanah bisa diakibatkan meningkatnya jumlah penduduk dan pendapatan. Total konsumsi kacang tanah pada tahun 2015 di tingkat rumah tangga sebesar 671,86 ribu ton dengan ketersediaan per kapita sebesar 2,63 kg/kap/th dan jumlah penduduk pertengahan tahun sebesar 255,46 juta orang. Periode tahun 2010-2015, rata-rata konsumsi kacang tanah sebesar 686,42 ribu ton, konsumsi ini lebih besar dibandingkan dengan rata-rata konsumsi nasional kacang tanah dua dekade terakhir hanya sebesar 557,891 ribu ton.

Permintaan konsumsi khususnya oleh industri makanan belum dapat dipenuhi oleh produksi kacang tanah dalam negeri. Menurut Kementerian Pertanian (2015b), neraca penawaran dan permintaan kacang tanah di Indonesia pada periode tahun 2015-2019 diperkirakan masih akan kekurangan kacang tanah untuk pemenuhan kebutuhan nasional dari 
produksinya. Laju kenaikan rata-rata nilai defisit ini diperkirakan sebesar $1,88 \%$ per tahunnya, sehingga diperkirakan Indonesia masih cenderung bergantung dari impor kacang tanah dari negara lain.

Data perkembangan luas panen kacang tanah di Indonesia juga menunjukkan bahwa pada tahun 1980 - 2015 luas panen rata-rata hanya meningkat sebesar $0,38 \%$ per tahun, dan menurun tahun 2011 - 2015 sebesar 4,48\% per tahun. Rata-rata luas panen di luar Pulau Jawa sebesar 149,44 ribu hektar dan sebesar 372,15 ribu hektar untuk Pulau Jawa. Kontribusi penurunan luas panen di luar Pulau Jawa sebesar 6,86\% per tahun sedangkan di Jawa sebesar 3,50\% .

Laju rata-rata pertumbuhan yang terjadi 5 tahun terakhir di Indonesia karena dipicu oleh pesaing komoditas lain yang secara ekonomis lebih menguntungkan, seperti padi, jagung, dan kedelai. Faktor yang mempengaruhi daya saing kacang tanah antara lain: harga, ketersediaan benih, kualitas benih, pemasaran, dan resiko hama (Kementerian Pertanian, 2015b). Petani akan menanam komoditi yang memiliki harga yang tinggi di tingkat produsen karena terkait dengan kesejahteraannya.

Berdasarkan uraian diatas maka penting untuk mengkaji faktor-faktor apa saja yang mempengaruhi respon penawaran kacang tanah di Indonesia, dan mengkaji perubahan harga terhadap perubahan penawaran kacang tanah atau elastisitasnya.

\subsection{Tujuan Penelitian}

Penelitian ini bertujuan untuk :

1. Menganalisis faktor-faktor apa saja yang mempengaruhi respon penawaran kacang tanah di Indonesia.

2. Menganalisis elastisitas penawaran kacang tanah di Indonesia.

\section{METODE PENELITIAN}

\subsection{Data dan Sumber Data}

Data yang digunakan adalah data sekunder berupa time series dari tahun 1990 sampai 2015. Data diperoleh dari Badan Pusat Statistik (BPS), Kementerian Pertanian, dan Food and Agriculture Organization (FAO).

\subsection{Penentuan Model}

Anindita (2004) menyatakan respon penawaran lebih cocok menggunakan pendekatan dinamis karena time lag value sangat berpengaruh pada penentuan penawaran berikutnya. Kebijaksanaan yang ditetapkan saat ini seringkali baru terlihat beberapa bulan bahkan beberapa tahun kemudian. Hal ini disebabkan, pertama, petani tidak bisa langsung mengantisipasi kebijakan tersebut, karena aktivitas pertanian mempunyai tenggang waktu (time lag). Kedua, kebijakan tersebut sering mempunyai pengaruh yang lambat terhadap perubahan atau perbaikan yang ingin dicapai.

Penelitian terdahulu mengenai respon penawaran komoditi pertanian sudah banyak dilakukan baik untuk komoditi kacang tanah dan komoditi lainnya. Namun penelitian tersebut memiliki kelemahan karena tidak mempertimbangkan adanya unsur waktu dalam analisisnya.

Peneliti terdahulu yang menggunakan model bersifat dinamik adalah: Putri (2011) pada komoditi jagung, Heriyanto, dkk. (2013) pada komoditi kacang tanah, Heriyanto dan Krisdiana (2011) pada komoditi ubi kayu, Kementerian Pertanian (2015) dalam berbagai komoditi, Ariningsih dan Tentamia (2004) pada komoditi bawang merah, Rahim (2016) pada komoditi ikan laut segar, Al-Mudatzir (2009) pada komoditi kedelai. Penelitian ini menggunakan model dinamik yaitu Nerlove, dimana output merupakan fungsi harga harapan, penyesuaian lahan dan beberapa variabel independen lainnya.

Model Nerlove merupakan kombinasi antara Partial Adjustment Model dan Adaptive Expectation Model :

$A_{t}^{*}=a_{0}+a_{1} P_{t}^{*}+a_{2} Z_{t}+u_{t}$

$A_{t}-A_{t-1}=\gamma\left(A_{t}^{*}-A_{t-1}\right)$

$P_{t}^{*}=\beta P_{t-1}+(1-\beta) P_{t-1}^{*}$

Dimana :

$A_{t}=$ Luas areal panen kacang tanah pada tahun ke-t

$A_{t}^{*}=$ Luas areal panen kacang tanah yang diinginkan pada tahun ke-t

$\boldsymbol{P}_{\boldsymbol{t}}=$ Harga kacang tanah pada tahun ke-t

$P_{t}^{*}=$ Harga kacang tanah yang diharapkan pada tahun ke-t 


$$
\begin{aligned}
Z_{t}= & \text { Variabel independen lain yang } \\
& \text { mempengaruhi penawaran kacang tanah } \\
& \text { pada tahun ke-t } \\
\beta= & \text { Koefisien harapan } \\
\gamma= & \text { Koefisien penyesuaian }
\end{aligned}
$$

Persamaan (2) dapat dituliskan lagi :

$$
\begin{aligned}
& A_{t}=A_{t-1}+\gamma\left(A_{t}^{*}-A_{t-1}\right) \\
& A_{t}=\gamma A_{t}^{*}+(1-\gamma) A_{t-1}
\end{aligned}
$$

Persamaan (1) disubstitusikan ke persamaan (5) diperoleh :

$A_{t}=\gamma a_{0}+\gamma a_{1} P_{t}^{*}+\gamma a_{1} Z_{t}+\gamma u_{t}+(1-\gamma) A_{t-1}$

Persamaan (3) disubstitusikan ke persamaan (6) diperoleh :

$A_{t}=\gamma a_{0}+\gamma a_{1} \beta P_{t-1}+\gamma a_{1}(1-\beta) P_{t-1}^{*}+$ $\gamma a_{2} Z_{t}+\gamma u_{t}+(1-\gamma) A_{t-1}$

Persamaan (6) dilag satu periode dan dikalikan dengan (1- $\beta)$ :

$A_{t-1}(1-\beta)=\gamma a_{0}(1-\beta)+\gamma a_{1}(1-\beta) P_{t-1}^{*}+$ $\gamma a_{2}(1-\beta) Z_{t-1}+\gamma(1-\beta) u_{t-1}+(1-\gamma)(1-$ B) $A_{t-2}$ (8)

Persamaan (8) dikurangi dengan persamaan (7) sehingga diperoleh model Nerlove sebagai berikut :

\section{$A_{t}=b_{0}+b_{1} P_{t-1}+b_{2} A_{t-1}+b_{3} A_{t-2}+b_{4} Z_{t}+$} $b_{5} Z_{t-1}+v_{t}$

Dimana :

$$
\begin{aligned}
& b_{0}=a_{0} \beta \gamma \\
& b_{1}=a_{1} \beta \gamma \\
& b_{2}=(1-\beta)+(1-\gamma) \\
& b_{3}=-(1-\beta)(1-\gamma) \\
& b_{4}=\gamma a_{2} \\
& b_{5}=-\gamma a_{2}(1-\beta) \\
& v_{t}=\gamma\left(u_{t}-(1-\beta) u_{t-1}\right)
\end{aligned}
$$

Eastisitas jangka pendek dirumuskan :

$$
\varepsilon_{s r}=\overline{\overline{P_{t}}}
$$

Elastisitas jangka panjang dirumuskan :

$$
\varepsilon_{l r}=\frac{b_{1}}{1-b_{2}-b_{3}} * \frac{\overline{P_{t}}}{\overline{A_{t}}}
$$

Merujuk persamaan (9), maka variabelvariabel yang digunakan dalam penelitian ini adalah: penawaran kacang tanah pada tahun ke-t $\left(\mathrm{AKT}_{\mathrm{t}}\right)$, penawaran kacang tanah pada tahun sebelumnya $\left(\mathrm{AKT}_{\mathrm{t}-1}\right)$, penawaran kacang tanah pada dua tahun sebelumnya $\left(\mathrm{AKT}_{\mathrm{t}-2}\right)$, harga komoditi pesaing yakni harga padi pada tingkat produsen pada tahun sebelumnya $\left(\mathbf{P P}_{\mathrm{t}-1)}\right)$, harga kedelai pada tahun sebelumnya (PKt-1), dan produksi kacang tanah pada tahun ke-t $\left(Q_{K T}\right)$.

\subsection{Pendugaan Model}

Model respon penawaran kacang tanah di Indonesia dianalisis dengan Ordinary Least Square (OLS). Kelebihan dari penggunaan model ini adalah (Koutsoyiannis, 1977) :

1. Penduga parameter diolah dengan menggunakan OLS memiliki sifat yang optimal.

2. Prosedur perhitungan dengan menggunakan OLS sangat sederhana dibandingkan dengan teknik ekonometrika lainnya, dan data yang dibutuhkan tidak terlalu banyak.

3. OLS merupakan metode yang umum digunakan untuk menduga hubungan dari model-model ekonomi.

4. Mekanisme dari metode OLS mudah mengerti.

5. OLS merupakan komponen yang penting dari sebagian besar metode ekonomi lainnya.

Selain itu, alasan penggunaan OLS bahwa penaksiran OLS dapat memenuhi beberapa sifat statistik yang diinginkan dengan asumsi-asumsi yang dibuat. Asumsi yang digunakan dalam analisis antara lain bahwa $\mathrm{Vt}_{\mathrm{t}}$ dan $\mathrm{u}_{\mathrm{t}}$ terdistribusi normal dengan: linier, tidak ada heteroskedatisitas, tidak ada multikoliniearitas, dan tidak ada autokorelasi. Pendugaan parameter diolah dengan software Eviews 7.

\subsection{Pengujian Model}

\subsubsection{Uji Stationeritas}

Pengujian ini dilakukan dengan menggunakan hipotesis :

$\mathrm{H}_{0}: \delta=0$ (time series tidak stationer)

$\mathrm{H}_{1}: \delta<0$ (time series adalah stationer)

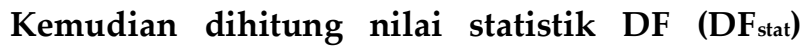
dengan rumus : 
$D F_{s t s t}=\frac{\delta-1}{\operatorname{se}(\delta)}$

Dimana :

$$
\begin{gathered}
\hat{\delta}=\text { nilai estimasi dari } \delta \\
\operatorname{se}(\hat{\delta})=\text { standard error dari } \delta
\end{gathered}
$$

Kriteria (Winarno, 2009) : Jika nilai absolut $\mathrm{DF}_{\text {statistik }} \leq$ nilai absolut $\mathrm{DF}_{\text {kritis, }}$ terima $\mathrm{H}_{0}$ berarti time series tidak stationer dan jika nilai absolut $D_{\text {statistik }}>$ nilai absolut $\mathrm{DF}_{\text {kritis, }}$ tolak $\mathrm{H}_{0}$ berarti time series stationer.

\subsubsection{Uji Multikolinieritas}

Multikolinieritas adalah kondisi adanya hubungan linier yang kuat antar variabel independen. Menurut Gujarati (1978), tandatanda adanya multikolinieritas adalah sebagai berikut :

1. Tanda koefisien tidak sesuai dengan yang diharapkan.

2. Nilai $\mathbf{R}^{2}$ tinggi, tetapi dalam uji individu banyak yang tidak nyata atau bahkan tidak nyata semua.

3. Matrix korelasi antar variabel tinggi (rij $>0,9)$. $\mathbf{R}^{2}<$ rij menunjukkan bahwa terjadi multikolinieritas.

\subsubsection{Uji Autokorelasi}

Uji DH digunakan untuk menguji apakah model persamaan mengalami serial korelasi (autokorelasi) atau tidak. Pada persamaan yang mengandung variabel independen beda kala (lagged independent variables), uji korelasi tidak menggunakan uji DW (Durbin-Watson), karena akan menyebabkan uji korelasi serial tidak valid (Koutsoyiannis, 1977). Jika statistik h lebih besar dari nilai kritis distribusi normal, maka model tidak mengalami serial korelasi. Uji statistik Durbin-h tidak valid apabila nilai var $\hat{b}$ lebih besar dari satu.

Untuk mengatasi kelemahan tersebut, dapat digunakan uji Breusch-Godfrey atau Langrange-Multiplier (LM). Kriterianya (Winarno, 2009) : bila nilai Probability $\left(\mathrm{Obs}^{*} R\right.$-squared) $>\alpha$ $=5 \%$, berarti tidak ada autokorelasi, dan bila nilai Probability $\left(\mathrm{Obs}^{*} \mathrm{R}\right.$-squared $) \leq \alpha=5 \%$, berarti ada autokorelasi.

\subsubsection{Uji Heteroskedastisitas}

Asumsi dalam model regresi adalah : (1) residual $\left(e_{\mathrm{i}}\right)$ memiliki nilai rata-rata nol, (2) residual memiliki varian yang konstan atau $\operatorname{var}\left(e_{i}\right)=\sigma^{2}$, dan (3) residual suatu observasi tidak saling berhubungan dengan residual observasi lainnya atau $\operatorname{cov}\left(e_{\mathrm{i}}, e_{\mathrm{j}}\right)=0$, sehingga menghasilkan estimator yang BLUE. Apabila asumsi (1) tidak terpenuhi, yang terpengaruh hanya slope estimator dan ini tidak membawa konsekuensi serius dalam analisis ekonometris. Sedangkan apabila asumsi (2) dan (3) dilanggar, maka akan membawa dampak serius bagi prediksi dengan model yang dibangun (Winarno, 2009).

Metode yang digunakan untuk mengidentifikasi ada-tidaknya masalah heteroskedastisitas adalah uji $A R C H$ (AutoRegressive Conditional Heteroscedasticity). Pengujian ini dilakukan dengan menggunakan hipotesis :

$\mathrm{H}_{0}$ : residual bersifat homoskedastis

$\mathrm{H}_{1}$ : residual bersifat heteroskedastis

Kriteria uji Arch (Winarno, 2009) : bila nilai Probability $>\alpha=5 \%$, berarti terima $\mathrm{H}_{0}$ berarti data bersifat homoskedastis, dan bila nilai Probability $\leq \alpha=5 \%$, berarti tolak $\mathrm{H}_{0}$ berarti data bersifat heteroskedastis

\subsubsection{Koefisien Determinasi $\left(\mathbf{R}^{2}\right)$}

Nilai koefisien determinasi $\left(R^{2}\right)$, yaitu untuk mengetahui ketepatan dari model yang dipakai. $R^{2}$ akan memberikan proporsi keragaman total dari variabel dependen yang mampu diterangkan oleh variabel independen.

$R^{2}=1-\frac{\sum(\hat{Y}-\bar{Y})^{2}}{\sum\left(Y_{i}-\bar{Y}\right)^{2}}=1-\frac{\sum e_{i}^{2}}{\sum y_{i}^{2}}$

dimana :

$\hat{Y} \quad=$ hasil estimasi nilai variabel dependen

$\bar{Y} \quad=$ nilai rata-rata variabel dependen

$Y_{i}=$ nilai observasi variabel dependen

$\mathrm{e}_{\mathrm{i}}=$ nilai variabel pengganggu (disturbances

error)

$Y_{i}^{2}=$ nilai deviasi variabel dependen

Semakin besar nilai $\mathbf{R}^{2}$ dari setiap persamaan, maka semakin besar variasi perubahan variabel dependen dapat dijelaskan oleh variabel independen dalam model.

\subsubsection{Uji F}

Overall test dengan uji $\mathrm{F}$, yaitu untuk mengukur tingkat pengaruh variabel-variabel 
independen secara serentak terhadap variabel dependen, dengan hipotesis :

$$
\begin{aligned}
H_{0}: & \beta_{1}=\beta_{2}=\beta_{\mathrm{k}}=0 \\
H_{1}: & \text { paling sedikit satu nilai } \beta_{\mathrm{k}} \text { tidak sama } \\
& \text { dengan nol }
\end{aligned}
$$

Kriteria pengujian adalah bila $F_{\text {hitung }}>\mathrm{F}$ tabel, maka $\mathrm{H}_{0}$ ditolak, berarti perilaku variabel independen secara serentak berpengaruh nyata terhadap variabel dependen, dengan tingkat kesalahan $\alpha$.

2.4.8. Uji $t$

Individual Test dengan uji-t, yaitu untuk mengetahui pengaruh variabel-variabel independen secara parsial (individu) terhadap variabel dependen. Hipotesis :

$$
\begin{aligned}
& H_{0}: \beta_{0}=0 \\
& H_{1}: \beta_{1}<0 \text { atau } H_{1}: \beta_{1}>0
\end{aligned}
$$

Kriteria pengujian adalah bila thitung $>t_{\text {tabel, }}$ maka $\mathrm{H}_{0}$ ditolak, berarti secara parsial variabel independen tersebut berpengaruh nyata terhadap perubahan variabel dependen pada tingkat kesalahan $\alpha$.

\section{HASIL DAN PEMBAHASAN}

\subsection{Hasil Uji Stasioneritas}

Sebelum menganalisis faktor-faktor yang mempengaruhi respon penawaran kacang tanah, maka semua data time series diuji stasioneritasnya dengan Dickey-Fuller Test. Hasil uji (Tabel 1) menunjukkan bahwa semua variabel stasioner pada tingkat first difference untuk $\alpha=$ $1 \%, \alpha=5 \%$, dan $\alpha=10 \%$ dimana nilai absolut $D F-$ Test lebih besar dari absolut test critical values, sehingga dapat digunakan untuk analisisnya selanjutnya.

Tabel 1. Hasil Uji Stasioneritas

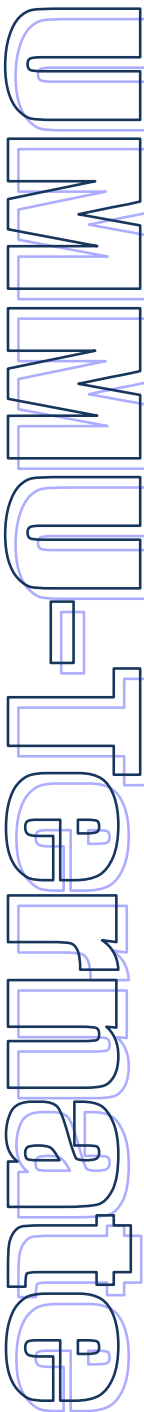

\begin{tabular}{clccc}
\hline No & \multicolumn{1}{c}{ Variabel } & DF-Test Statistic & Prob. & Kesimpulan \\
\hline 1 & Penawaran kacang tanah pada tahun ke-t & -6.238380 & 0.0000 & Stasioner \\
2 & Penawaran kacang tanah pada 1 tahun sebelumnya & -6.253867 & 0.0000 & Stasioner \\
3 & Penawaran kacang tanah pada 2 tahun sebelumnya & -6.243614 & 0.0000 & Stasioner \\
4 & Harga kacang tanah pada 1 tahun sebelumnya & -4.033915 & 0.0051 & Stasioner \\
5 & $\begin{array}{l}\text { Harga kedelai di tingkat produsen pada 1 tahun } \\
\text { sebelumnya }\end{array}$ & -4.640953 & 0.0012 & Stasioner \\
6 & $\begin{array}{l}\text { Harga padi di tingkat produsen pada 1 tahun } \\
7\end{array}$ & -3.412020 & 0.0211 & Stasioner \\
\hline
\end{tabular}

Keterangan :

- Test Critical Value : $1 \%=-3.737853,5 \%=-2.991878,10 \%=-2.635542$

\subsection{Pendugaan Model}

Hasil uji multikolinearitas menunjukkan nilai matriks korelasi antar variabel rata-rata dibawah 0.9. Uji heteroskedastik menunjukkan bahwa nilai Prob. $\chi^{2}=0,6377$ lebih besar dari $\alpha=$ $5 \%$, berarti data bersifat homoskedatis. Serta uji LM menunjukkan nilai Prob. $\chi^{2}=0,0855$ lebih besar dari $\alpha=5 \%$, mengindikasikan bahwa tidak ada masalah autokorelasi.

Hasil pendugaan model metode OLS menunjukkan bahwa $R^{2}$ sistem sebesar 0,9794 . Hal ini berarti seluruh variabel independen dalam model dapat menerangkan perilaku model sebesar $97,94 \%$, sedangkan sisanya diterangkan oleh variabel-variabel diluar model. Nilai statistik F sebesar 0,0000 berarti variabel independen secara bersama-sama berpengaruh nyata terhadap variabel dependen. Untuk menguji apakah masing-masing variabel berpengaruh nyata secara statistik terhadap variabel dependen maka digunakan uji statistik $t$.

Berdasarkan hasil dugaan tersebut, dapat disimpulkan bahwa model yang digunakan dalam penelitian ini cukup representatif dalam menjelaskan fenomena respon penawaran kacang tanah di Indonesia.

\subsection{Faktor-Faktor yang Mempengaruhi Respon} Penawaran Kacang Tanah di Indonesia Hasil analisis faktor-faktor yang mempengaruhi respon penawaran kacang tanah di Indonesia tersaji dalam Tabel 1 berikut ini.

Pengaruh masing-masing variabel terhadap respon penawaran kacang tanah di Indonesia 
berdasarkan uji-t. Tabel distribusi $t$ dicari pada $\alpha$ $=5 \%$ dan $\alpha=20 \%$ dengan derajat kebebasan (df) n-k-1 atau 26-6-1 = 19 (n adalah jumlah data dan $k$ adalah jumlah variabel bebas). Dengan pengujian 1 sisi diperoleh untuk $t$ tabel sebesar 2,093 (signifikansi $=0,05$ ) dan 1,328 (signifikansi = $0,20)$. Hasil analisis menunjukkan bahwa variabel yang berpengaruh nyata terhadap respon penawaran jagung di Indonesia adalah harga kacang tanah pada tahun sebelumnya, penawaran kacang tanah pada tahun sebelumnya, harga padi pada tahun sebelumnya, harga kedelai pada tahun sebelumnya, dan produksi kacang tanah pada tahun $t$.

Tabel 1. Faktor-Faktor yang Mempengaruhi Respon Penawaran Kacang Tanah di Indonesia

\begin{tabular}{|c|c|c|c|c|}
\hline & Variabel & Koefisien & t-Statistik & Prob \\
\hline $\mathbf{P K T}_{\mathrm{t}-1}$ & & 5.627143 & $1.391445^{* *}$ & 0.1802 \\
\hline $\mathrm{AKT}_{\mathrm{t}-1}$ & & -0.186904 & $-2.656661^{*}$ & 0.0156 \\
\hline $\mathrm{AKT}_{\mathrm{t}-2}$ & & -0.047200 & $-0.797819^{n s}$ & 0.4348 \\
\hline $\mathbf{P P}_{\mathrm{t}-1}$ & & -32.29603 & $-2.849276^{*}$ & 0.0103 \\
\hline $\mathbf{P K}_{\mathrm{t}-1}$ & & -13.31372 & $-2.298339 *$ & 0.0331 \\
\hline $\mathrm{QKT}_{\mathrm{t}}$ & & 0.767122 & $14.96576^{*}$ & 0.0000 \\
\hline R-squa & ared & 0.979401 & & \\
\hline Adjust & ed R-squared & 0.972896 & & \\
\hline F-stati & stic & 150.5614 & & \\
\hline $\operatorname{Prob}(F$ & -statistic) & 0.000000 & & \\
\hline \multicolumn{5}{|c|}{ Keterangan: } \\
\hline$A K T_{t}$ & \multicolumn{4}{|c|}{$=$ Penawaran kacang tanah Indonesia pada tahun ke-t } \\
\hline$P K T_{t-1}$ & \multicolumn{4}{|c|}{$=$ Harga kacang tanah Indonesia pada tahun sebelumnya } \\
\hline$A K T_{t-1}$ & \multicolumn{4}{|c|}{$=$ Penawaran kacang tanah Indonesia pada tahun sebelumnya } \\
\hline$A K T_{t-2}$ & \multicolumn{4}{|c|}{$=$ Penawaran kacang tanah Indonesia 2 tahun sebelumnya } \\
\hline$P P_{t-1}$ & \multicolumn{4}{|c|}{$=$ Harga padi di tingkat produsen pada tahun sebelumnya $(\mathrm{Rp} / \mathrm{kg})$} \\
\hline$P K_{t-1}$ & \multicolumn{4}{|c|}{$=$ Harga kedelai di tingkat produsen pada tahun sebelumnya $(\mathbf{R} p / \mathrm{kg})$} \\
\hline$Q K T_{t}$ & \multicolumn{4}{|c|}{$=$ Produksi kacang tanah Indonesia pada tahun ke-t } \\
\hline \multicolumn{5}{|c|}{ Keterangan tingkat nyata: } \\
\hline * & nyata & \multirow{2}{*}{\multicolumn{3}{|c|}{ nyata pada tingkat kesalahan $5 \%(\alpha=0.05)$}} \\
\hline ** & nyata & & & nyata pada tingkat kesalahan $20 \%(\alpha=0.20)$ \\
\hline$n s$ & tidak 1 & \multicolumn{3}{|c|}{ tidak nyata } \\
\hline
\end{tabular}

Harga kacang tanah pada tahun sebelumnya berpengaruh nyata dan positif terhadap respon penawaran kacang tanah di Indonesia. Nilai koefisien regresi sebesar 5,627 artinya bahwa setiap peningkatan kacang tanah pada tahun sebelumnya sebesar Rp 1 maka akan menyebabkan peningkatan penawaran kacang tanah sebesar 5,627 kg. Harga kacang tanah di tingkat produsen ditentukan oleh mekanisme pasar, sehingga peningkatan luas areal kacang tanah merupakan respon terhadap harga jual kacang tanah yang cenderung meningkat sebagai akibat ketidakseimbangan antara penawaran dan permintaan kacang tanah domestik. Menurut Heriyanto, dkk (2013), pengaruh harga tidak direspon langsung oleh petani, sebab aktivitas pertanian mempunyai tenggang waktu (time lag) mulai dari pengambilan keputusan berproduksi, realisasi produksi hingga panen.

Penawaran kacang tanah tahun sebelumnya berpengaruh nyata dan negatif terhadap penawaran kacang tanah. Nilai koefisien regresi adalah $\mathbf{- 0 . 1 8 7}$, berarti jika terjadi kenaikan penawaran jagung pada tahun sebelumnya sebesar $1000 \mathrm{~kg} / \mathrm{ha}$, maka kenaikan penawaran jagung ini akan direspon oleh petani dengan mengurangi penawaran pada tahun sekarang sebesar $187 \mathrm{~kg}$. Hasil penelitian ini sejalan dengan Heriyanto, et al. (2013) dimana keputusan petani menawarkan kacang tanah pada tahun berlaku merujuk pada pengalamannya menjual kacang tanah pada tahun sebelumnya. Bilamana penawaran kacang tanah pada tahun sebelumnya tinggi, maka diasumsikan masih ada kacang tanah berupa stok 
yang belum terjual sehingga penawaran kacang tanah akan berkurang pada tahun sekarang.

Penawaran kacang tanah pada dua tahun sebelumnya tidak berpengaruh nyata terhadap penawaran kacang tanah di Indonesia. Hasil penelitian ini sejalan dengan Heriyanto, et al. (2013), karena petani melakukan pengambilan keputusan dalam berusahatani adalah berdasarkan hasil periode sebelumnya.

Harga padi di tingkat produsen pada tahun sebelumnya berpengaruh nyata dan negatif terhadap penawaran kacang tanah Indonesia. Koefisien regresi sebesar $-32,296$ artinya bilamana harga padi meningkat sebesar Rp 1 maka akan menyebabkan penurunan penawaran kacang tanah sebesar $32,296 \mathrm{~kg}$. Hasil penelitian ini sejalan dengan Heriyanto, et al (2013). Bila harga padi di tingkat produsen meningkat dibandingkan harga kacang tanah, tentunya petani merasa menanam padi akan lebih menguntungkan sehingga petani akan lebih memilih menanam padi pada musim tanam berikutnya. Perubahan komoditi ini tentunya akan mengurangi luas panen kacang tanah dan berimbas pada penawaran, dengan asumi faktorfaktor lain tetap.

Harga kedelai di tingkat produsen pada tahun sebelumnya berpengaruh nyata dan negatif terhadap penawaran kacang tanah Indonesia. Koefisien regresi sebesar $-13,314$ berarti bilamana harga kedelai di tingkat produsen meningkat sebesar $R p \quad 1$ maka penawaran kacang tanah akan menurun sebesar $13,314 \mathrm{~kg}$. Kondisi ini dimungkinkan karena petani akan beralih menanam komoditi yang memiliki nilai jual yang lebih tinggi. Hal ini berdampak menurunnya areal panen kacang tanah, selanjutnya penawaran kacang tanah pun akan menurun, dengan asumsi faktor-faktor lain yang mempengaruhinya tetap.

Produksi kacang tanah pada tahun $t$ berpengaruh nyata dan positif terhadap penawaran kacang tanah di Indonesia. Nilai koefisien regresi sebesar 0,767 berarti bilamana produksi kacang tanah meningkat sebesar $1 \mathrm{~kg}$ maka penawaran kacang tanah Indonesia pada tahun $t$ pun meningkat sebesar $0,767 \mathrm{~kg}$. Hasil penelitian ini sejalan dengan Heriyanto, et al (2013). Produksi kacang tanah yang meningkat dan didukung dengan harga yang tinggi akan mendorong petani untuk tetap menanam kacang tanah dan meningkatkan areal tanam di musim berikutnya sehingga penawarannya pun meningkat. Selain itu, bila produksi tidak terserap dipasar maka dapat dijadikan stok karena daya simpan kacang tanah adalah satu tahun.

\subsection{Elastisitas Penawaran}

Elastisitas penawaran mengukur respon kuantitas yang ditawarkan terhadap perubahan harga. Nilai elastisitas penawaran kacang tanah jangka pendek dan jangka panjang dapat dilihat pada Tabel 2 berikut ini.

Tabel 2 . Elastisitas Penawaran Kacang Tanah Jangka Pendek dan Jangka Panjang

\begin{tabular}{lcc}
\hline \multicolumn{1}{c}{ Elastisitas } & Jangka Pendek & Jangka Panjang \\
\hline Harga sendiri : & & \\
Kacang Tanah & 5,627 & 4,741 \\
Harga Silang: & & $-27,210$ \\
Kacang Tanah terhadap Padi & $-32,296$ & $-11,217$ \\
Kacang Tanah terhadap Kedelai & $-13,314$ & \\
\hline
\end{tabular}

Tabel 2 menunjukkan bahwa selama periode analisis (1990-2015), elastisitas penawaran kacang tanah terhadap harga sendiri baik dalam jangka pendek sebesar 5,627 dan 4,741 pada jangka panjang. Artinya bila terjadi peningkatan harga kacang tanah sebesar $1 \%$ maka penawaran kacang tanah pun meningkat sebesar $5,627 \%$ pada jangka pendek dan sebesar $4,741 \%$ pada jangka panjang. Elastisitas penawaran kacang tanah terhadap harga sendiri dalam jangka pendek dan panjang bersifat elastis, artinya bila harga naik/turun sebesar $1 \%$, maka penawaran akan naik/turun lebih dari $1 \%$. Koefisien elastisitas penawaran yang lebih besar dari satu menunjukkan jumlah barang yang ditawarkan sangat dipengaruhi oleh perubahan harga. Harga 
kacang tanah yang tinggi dibandingkan komoditi padi dan kedelai menjadi daya tarik petani untuk merespon perubahan penawarannya dengan cepat. Dengan kata lain, petani akan terdorong untuk menanam kacang tanah sehingga produksi dan penawarannya pun meningkat.

Elastisitas penawaran kacang tanah terhadap harga padi pada tahun sebelumnya bernilai negatif yaitu $-32,296$ pada jangka pendek dan $-27,210$ pada jangka panjang. Hal ini berarti peningkatan harga padi sebesar satu persen akan menurunkan penawaran kacang tanah sebesar 32,296 persen pada jangka pendek dan 27,210 persen pada jangka panjang. Hasil penelitian ini sejalan dengan penelitian Heriyanto et al. (2013). Bila harga padi di tingkat produsen pada tahun sebelumnya meningkat maka petani akan mengalokasikan lahannya untuk menanam padi, sehingga luas areal tanam dan panen kacang tanah akan menurun, produksi menurun, dan akhirnya penawaran kacang tanah pun menurun. Nilai elastitisitas kurang dari 1 berarti bersifat inelastis dimana persentase perubahan penawaran kacang tanah lebih besar dari persentase perubahan harga pada tahun berlangsung.

Elastisitas penawaran kacang tanah terhadap harga kedelai pada tahun sebelumnya bernilai negatif yaitu $-13,314$ pada jangka pendek dan -11.217 pada jangka panjang. Hal ini berarti peningkatan harga kedelai sebesar satu persen akan menurunkan penawaran jagung sebesar 13,314 persen pada jangka pendek dan 11.217 persen pada jangka panjang. Nilai elastitisitas kurang dari 1 berarti bersifat inelastis dimana persentase perubahan penawaran kacang tanah lebih besar dari persentase perubahan harga kedelai pada tahun sebelumnya. Ketika harga kedelai di tingkat produsen pada tahun sebelumnya meningkat maka petani pun akan mengalokasikan lahannya untuk menanam kedelai dan dampak akhirnya adalah menurunnya penawaran kacang tanah.

\section{PENUTUP}

4.1. Kesimpulan

Berdasarkan hasil penelitian maka disimpulkan hal-hal berikut :'

1. Faktor-faktor yang mempengaruhi respon penawaran kacang tanah di Indonesia adalah : harga kacang tanah pada tahun sebelumnya, penawaran kacang tanah pada tahun sebelumnya, harga padi pada tahun sebelumnya, harga kedelai pada tahun sebelumnya, dan produksi kacang tanah pada tahun $\mathbf{t}$.

2. Elastisitas penawaran harga sendiri dalam jangka pendek dan panjang bersifat elastis. Sedangkan elastisitas harga silang terhadap harga padi pada tahun sebelumnya dan terhadap harga kedelai tahun sebelumnya bersifat inelastis.

\subsection{Saran}

Berdasarkan hasil penelitian maka disarankan:

1. Kondisi harga kacang tanah pada tahun sebelumnya, penawaran kacang tanah pada tahun sebelumnya, harga padi pada tahun sebelumnya, harga kedelai pada tahun sebelumnya, dan produksi kacang tanah pada tahun $t$; dapat digunakan sebagai pertimbangan untuk menanam kacang tanah

2. Dalam jangka panjang perlu upaya untuk meningkatkan penawaran kacang tanah melalui peningkatan produksi dan produktivitas sehingga mampu memenuhi permintaan kacang tanah dalam negeri

\section{DAFTAR PUSTAKA}

Al-Mudatsir, Muhammad Iqbal, 2009. Analisis Faktor-Faktor Yang Memengaruhi Respon Penawaran Kacang Kedelai Di Indonesia, Fakultas Ekonomi Dan Manajemen, Institut Pertanian Bogor. Anindita, Ratya, 2004. Pemasaran Hasil Pertanian, Papyrus, Surabaya 
*

Ariningsih, Ening dan Tentamia, Mari Komariah, 2004. Faktor-Faktor Yang Mempengaruhi Penawaran Dan Permintaan Bawang Merah Di Indonesia, Pusat Penelitian dan Pengembangan Sosial Ekonomi Pertanian, Bogor

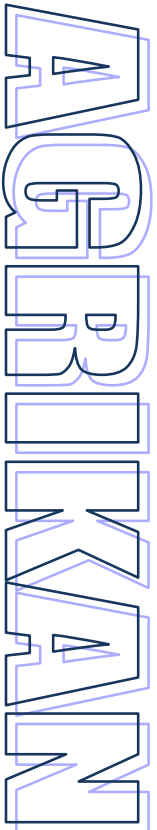

Heriyanto dan Krisdiana, R., 2011. Model Respon Penawaran Komoditas Ubikayu Di Indonesia, Majalah Ekonomi Tahun XXI, No. 3 Desember 2011

Heriyanto, Ratya Anindita, Ratih Yuli Lestari, 2013. Prosiding Seminar Hasil Penelitian Tanaman Aneka Kacang dan Umbi 2013

Kementerian Pertanian, 2015a. Rencana Strategis Kementerian Pertanian Tahun 2015-2019, Biro Perencanaan, Sekretariat Jenderal, Jakarta 2015b. Outlook Komoditas Pertanian Subsektor Tanaman Pangan: Kacang Tanah, Pusat Data dan Sistem Informasi Pertanian, Jakarta

Koutsoyiannis, A., 1977. Theory of Econometrics. The Macmillan Press Ltd, USA.

Nerlove M. 1956. Estimates of The Elasticities of Supply of Selected Agricultural Commodities, Journal of Farm Economics. 38:496-509

Nerlove M., 1958. Distributed and Estimation of Lung Run Supply and Demand Elasticities: Theoritical Consideration. Journal of Farm Economics. 9:301-311

Putri, Hervikarani Utomo, 2011. Respon Penawaran Jagung di Klaten. Universitas Sebelas Maret Surakarta

Rahim, A., 2016. Respon Penawaran Ikan Laut Segar, Jurnal Scientific Pinisi, Volume 2, Nomor 2,Oktober 2016, hlm. 79-85

Winarno, W. W., 2009. Analisis Ekonometrika dan Statistika Dengan Eviews. Edisi Kedua, UPP STIM YKPN, Yogyakarta 